THIS IS AN EARLIER VERSION OF THE MANUSCRIPT. FOR THE FINAL VERSION, PLEASE CHECK THE JOURNAL WEBSITE: Serrano, R., Tragant, E., \& Llanes, À. (2014). Summer English courses abroad vs. "at home". ELT Journal, 68, 397-409.

\title{
Summer English courses abroad versus 'at home'
}

\author{
Raquel Serrano, Elsa Tragant, and Àngels Llanes
}

\begin{abstract}
The purpose of this study is to examine two L2 learning contexts (study abroad versus EFL intensive instruction at home) in terms of language development and learners' characteristics (including students' initial predisposition to learn English, and their experience in the programme they enrolled in). Two groups of teenagers were considered: one group $(\mathrm{n}=58)$ received intensive classroom instruction for four weeks in their home country (Spain), and another group $(n=54)$ spent a comparable amount of time abroad (UK), where they also attended language lessons. The learners performed two written tasks twice (at the beginning and at the end of their summer programme) and they filled in a questionnaire about their experience while studying. The results of our analyses suggest that, while the L2 develops in a comparable way in the two contexts, learners' profiles and experiences are slightly different.
\end{abstract}

\section{Introduction}

Research on the effect of learning context on second language acquisition has become more and more popular in the last few years, with most research generally focusing on adult college students spending one or two semesters at a university abroad. This context is referred to as 'study abroad' (SA) or residence abroad, and it usually combines both L2 instruction with naturalistic exposure to the target language. Most research (for example Segalowitz and Freed 2004)compares the L2 development of college students in the SA context with the type of language learning that takes place in students' home university ('at home', AH), where exposure to the L2 is more limited and typically restricted to the classroom. Studies on this topic have reported certain benefits of the SA context, which tend to be more obvious in the case of oral fluency (Segalowitz and Freed op.cit.; Mora and Valls-Ferrer 2012). This focus on adults is not surprising, as this type of exchange programme is now quite popular in universities across Europe, America, and Asia. Additionally, adult students are more likely than younger learners to travel abroad to improve their second language skills. Despite this, there are also many children and 
teenagers who go abroad to learn an L2 (especially English) and very little research exists analysing how these younger participants develop their L2 skills in an SA setting as opposed to a classroom setting at home.

Llanes and Muñoz (2013) examined children aged 10 who spent three months in an SA context as part of their primary education, and found that these learners significantly outperformed their peers (who stayed in the AH setting) in most aspects of L2 that they analysed, especially in oral fluency. Short stays abroad in summer are more common for children and teenagers than longer SA programmes, and as noted above research focusing on this population is scarce. The present study aims to fill this gap by including teenagers aged 13-17 years of age enrolled in a short-term summer programme abroad and compare this context with a summer intensive EFL programme at home (4.5 hours of instruction per day, or 22.5 hours per week). We believe that this comparison is fairer than the comparisons normally established in research (Serrano, Llanes, and Tragant 2011) on learning context, which include SA versus more typical AH programmes that provide a maximum of 2-4 hours of instruction per week. In the programmes that we are examining, the hours of exposure to the L2 are more comparable (more details about this will be provided in the Method section).

When researching learning contexts, it is important to consider the opportunities the students have (or, more importantly, seek) both inside and outside the classroom to use the language, as well as their motivation to learn and their perception of their learning progress. Individual differences have long been recognized as important predictors of second language acquisition regardless of language context (Dörnyei and Skehan 2003), and many researchers have found that factors such as learning attitude/motivation (Hernández 2010), L2 practice (DeKeyser 2007), or age (Brecht, Davidson, and Ginsberg 1993; Llanes and Muñoz op.cit.) partly determine language development in the SA setting.

Our study aims to fill the gaps in the literature on the effects of learning context on language development that have been identified in this literature review. First, we are going to investigate teenagers’ L2 performance and development in two different shortterm EFL programmes (SA versus intensive $\mathrm{AH}$ ). Additionally, we are going to present a 
description of the learners' profiles and experiences in the two contexts in order to be able to understand their language development more deeply. More specifically, the objective of the present study is to answer the following research questions:

1 Do EFL learners have enough time to improve their L2 significantly during a short summer programme?

2 Do teenagers in an SA programme improve their English more than their peers who receive intensive instruction $\mathrm{AH}$ as evaluated via a written instrument?

3 What are the study profiles of the participants in the two programmes, in terms of their predisposition to and experiences in the two contexts?

\section{Method}

\section{Programmes and participants}

Two programmes were considered for this study: SA $(n=54)$ and EFL intensive instruction (AH) $(n=58)$. The two programmes had in common the fact that they provided short (less than one month) but concentrated exposure to the target language during the summer, and both included classroom instruction. Additionally, both programmes recruited EFL learners from Catalonia, Spain, and were thus CatalanSpanish bilinguals. The participants' age ranged from 13 to 17 years old. The mean age for the SA programme was 14.57 and for the EFL intensive programme 14.17. Information about the participants and the programmes was obtained through questionnaires the students and teachers filled in, and through field observations.

The SA participants spent three weeks in the south of England during the month of July. The students stayed in residence halls together with other international students. The SA programme was a combination of naturalistic immersion (natural exposure to the L2 in the target-language country) plus classroom instruction. In terms of instruction, the students attended classes in the morning Monday through Friday for three hours. Most class time was devoted to practising students' speaking/listening skills rather than writing/reading skills, and the classes were more focused on vocabulary than grammar. 
The students participating in the study were grouped according to their proficiency level

and were mixed with other international students. Apart from the class, the students could freely interact with international students or with adult English native speakers (NSs) during their meals, and during the activities that were organized and coordinated by English-speaking professionals in the afternoon (sports, arts, and crafts, etc.) and in the evening (disco, karaoke, etc.) During the weekend, there were no organized activities that encouraged our participants to mix and interact with other English speakers/learners, but they could do so under their own initiative.

The intensive EFL programme (AH) took place in the participants' home city (Barcelona, Spain) during the month of July. This programme was offered in a private institution, where all the teachers were NSs of British English. The programme lasted for four weeks, in which participants received a total of 90 hours of EFL instruction, i.e. 4.5 hours per day or 22.5 hours per week. The classes included both explicit teaching of grammar and vocabulary as well as communicative practice, games, and listening exercises. In this context, L2 exposure took place mostly within the classroom; however, as it was an intensive course, the students were required to do homework almost every day.

\section{Instruments and procedure}

Two writing tasks were used in order for us to examine L2 performance/development (both tasks were used as pre- and post-study tests of performance. The two tasks were related to the same comic strip, called 'Tony and Tina' (Viladoms 2009), which represented a little adventure that Tony had while preparing his breakfast (see Appendix A). In the first task, the text in 8 of the 16 speech bubbles was omitted and the students had to fill in those bubbles in order to complete the story successfully. The students had seven minutes to perform this task and they were instructed to write as much as they could. Fifteen minutes later, the students were asked to retell the comic strip as a story in their own words (i.e. in a narrative form), starting with the sentence 'One day, Tony ...'. In order to do that, the students were given the comic strip again but this time without any text. The students had ten minutes to write as many words as possible to complete the written narrative. Despite the fact that these tasks were written (which facilitated the data collection process), it must be pointed out that we were not examining writing per se 
(organisation, paragraph development, connectors, etc.), but language proficiency via a written instrument. Additionally, the tasks included were timed (participants did not have time to plan them, as is the case with most written tasks) and they were a dialogue and a narrative, both of which require skills that are not so different to equivalent tasks in the oral mode.

The two tasks were analysed in terms of fluency (total number of words written per task), lexical complexity, and accuracy (which are common dimensions that are used to examine learners' L2 performance), and we adopted some of the most frequently used measures to analyse those dimensions (see Table 1). As can be seen, we used the same measures for fluency and lexical complexity in the two tasks, but we considered that it was more appropriate to use two different measures in the case of accuracy.

[Table 1]

Students' study profiles were obtained through a self-reported written questionnaire. We examined learners' initial predisposition, English use in the two contexts, and students' perceptions of their programmes (for more details on how those factors were operationalized, see Table 4 in the Results section).

The present study had a pre-test/post-test design, using the two written exercises outlined above. The pre-test took place at the beginning of the programme and the post-test at the end. Even though the programmes had a different duration (the $\mathrm{AH}$ intensive programme was longer), the actual days of exposure to the L2 between pre- and post-test were the same (i.e. 18). The questionnaire was administered only once at the post-test.

\section{Results}

First, we will present the results for students' performance on the English language tasks. As the learners completed the tasks twice, we decided to perform a Repeated Measures (RM) Analysis of Variance (ANOVA), with time (difference between pre-test/post-test scores) as the within-subject variable and context (SA versus $\mathrm{AH}$ ) as the between-subject variable. The descriptive statistics including means and standard deviations (SD) presented in Table 2 (Bubbles task) and Table 3 (Narrative) indicate that the students in 
the SA context always outperformed those in the AH intensive context. Additionally, it can be observed that the scores in the post-test tend to be higher than those of the pre-test. It should be noticed that the accuracy measure for the Bubbles task works in a different way from the other measures, as lower scores are positive (meaning fewer errors).

[Table 2]

[Table 3]

The results of the RM ANOVAs (see Appendix B for details) suggest that over time, the improvement in participants' performance on the tests on all measures was significant, except for accuracy in the Bubbles task. This means that, considering all the students together, L2 gains in fluency and lexical richness in the two tasks and accuracy in the narrative task were statistically significant $(p<.05)$. Additionally, the results indicate that the effect of context was also significant, with SA learners performing significantly better than their partners in the AH context in all measures both at the start and end of the programmes, except for accuracy in the Bubbles task. However, no interaction was found between time (pre-/post-test) and context (abroad/at home), which indicates that the learners in the two contexts under analysis made comparable L2 gains in their respective programmes.

Finally, we will present the information concerning learners' study profiles in the two contexts. A summary of the most important results appears in Table 4. In parenthesis, we indicate the question (Q) from the questionnaire that targets each aspect (see Appendix C for the relevant questions). These results will be discussed in the following section.

[Table 4]

\section{Discussion and conclusion}

The aim of this study was to examine L2 development abroad versus 'at home', as well as to analyse the study profiles of the learners enrolled in two short-term EFL programmes. According to our results, the answer to our first research question would be affirmative: a short summer programme (whether abroad or at home) is indeed enough for EFL learners to make significant progress in their L2, especially in the case of fluency and vocabulary. These results validate the benefit of these popular programmes in which 
many teenagers enrol every summer, suggesting that L2 gains do certainly occur after such a short time. These gains are probably due to the fact that the contact with the L2 is quite intensive and continuous (at least five out of seven days or 20 hours per week). In fact, we have collected data for the Bubbles task from learners who did not receive intensive instruction during the same period (i.e. 18 days) and they did not significantly improve their performance between pre- and post-test, which supports the idea that intensive L2 exposure is indeed beneficial.

However, and in answer to the second research question, the learners in the SA context did not make more gains than their peers who stayed $\mathrm{AH}$ and only received classroom instruction (although their performance was always superior, both at pre- and post-test). This finding contradicts previous studies that have compared the SA and the AH settings; however, the $\mathrm{AH}$ programmes that were included in those studies were not intensive and provided very few hours of instruction, which again provides evidence for the positive effect of intensity in EFL instruction. Other reasons for this finding might be related to the students' use of English during the summer, which was one of the aspects examined in the third research question. In fact, the SA learners did not take full advantage of the naturalistic setting in which they were learning, and most of their exposure to English took place in the English classroom. In general, the students reported little use of English outside the class, and the majority of them used the language only a few times in the dining room, residence hall, or during their weekends. In fact, the aspects that were most controlled (EFL class and afternoon activities) were the ones that led to more language use. Students' reports are validated by our own observations ${ }^{1}$ the learners did indeed spend most of their free time with their L1-speaking peers).

When considering the information about learners' study profiles (third research question), it becomes apparent that the learners in the SA context had a slightly better predisposition: there were more learners who enrolled in the programme at their own initiative than in the AH programme, and the SA participants' motivation to learn English was more intrinsic (personal positive feelings towards the language, pleasure in communicating in English, etc.), while for most of the AH participants their motivation was due to the importance of English in our current world. Additionally, there were more learners on the SA programme than on the AH programme who were sure they would 
like to repeat the experience, which provides evidence for their positive feelings towards their stay. This positive SA experience is not related necessarily to the use of English or the amount of perceived progress in this language (which in fact is lower than in the $\mathrm{AH}$ context), but to the fact that the participants abroad had (and took advantage of) opportunities for personal growth that were available there but not in the AH context: for example meeting new people (mostly international students) and travelling to different cities, which led to an expansion of their world. These aspects, together with being in touch with native speakers, were perceived as the aspects the SA participants valued the most, as well as the aspects that helped them learn English the most (versus the features immediately related to the classroom practice that were mentioned by the AH learners). Similar accounts of personal growth by university students in short SA programmes are reported in the literature (Jackson 2006).

Considering all our results together, it can be said that, while from a language point of view doing an intensive English course in an English-speaking country is as beneficial as doing it in the participants' home country, the SA setting provides learners with opportunities that go beyond the use of the L2 in a naturalistic setting. The SA programme is indeed an 'enriching experience' for the learners, in which they get to know a different country, different habits, and native speakers as well as other international students. Being as highly motivated to repeat the experience as they are, these learners will likely find themselves abroad in the future and it is probable that L2 gains will be a consequence of that increased contact.

Another important finding from our study is that when the time abroad is supervised or structured (in the form of L2 classes or afternoon activities), the students certainly use the L2 more often, which reflects what Tragant (2012) reported for SA university students. As a consequence, more L2 gains might be brought about if SA programme coordinators create as many opportunities as possible for $\mathrm{L} 2$ learners to interact in the L2, both with other international students and with native English speakers, and to minimize the hours of unsupervised/unstructured time spent with L1-speaking peers (especially during weekends).

To conclude, our study has shown that a summer intensive English course (whether 
abroad or 'at home') is beneficial for language learning and we attribute this result to the positive effects of intensive exposure to the language (Muñoz 2012). Considering our findings, it is up to the parents whether they enrol their children and teenagers in a programme that just offers intensive English practice (AH context) or a more international/intercultural experience (SA context), which in turn might be more motivating for the teenagers, but which is generally more expensive as well.

Final version received November 2013

\section{Note}

1 The authors of the present study observed the participants (both the study abroad and the at home ones) for two of days in order to triangulate the data obtained. During these observations, special attention was paid to the amount and type of interaction and practice of the L2, and the types of activities in which the participants engaged.

\section{References}

Brecht, R. D., D. Davidson, and R. B. Ginsberg. 1993. 'Predictors of foreign language gain during study abroad'. NFLC Occasional Papers. Washington, DC: National Foreign Language Center.

DeKeyser, R. M. 2007. 'Study abroad as foreign language practice’ in R. M. DeKeyser (ed.). Practice in a Second Language: Perspectives from Applied Linguistics and Cognitive Psychology. New York, NY: Cambridge University Press.

Dörnyei, Z. and P. Skehan. 2003. 'Individual differences in second language learning’ in C. J. Doughty and M. H. Long (eds.). The Handbook of Second Language Acquisition. Oxford: Blackwell Publishing.

Hernández, T. 2010. 'Promoting speaking proficiency through motivation and interaction: the study abroad and classroom learning contexts’. Foreign Language Annals 43/4: 650-70.

Jackson, J. 2006. 'Ethnographic pedagogy and evaluation in short-term study abroad’ in M. M. Byram and A. Feng (eds.). Living and Studying Abroad: Research and Practice. Clevedon: Multilingual Matters.

Llanes, À. and C. Muñoz. 2013. 'Age effects in a study abroad context: children and adults 
studying abroad and at home’. Language Learning 63/1: 63-90.

Mora, J. C. and M. Valls-Ferrer. 2012. 'Oral fluency, accuracy, and complexity in formal instruction and study abroad learning contexts’. TESOL Quarterly 46/4: 610-41.

Muñoz, C. (ed.). 2012. Intensive Exposure Experiences in Second Language Learning.

Clevedon: Multilingual Matters.

Segalowitz, N. and B. Freed. 2004. 'Context, contact, and cognition in oral fluency acquisition: learning Spanish in at home and study abroad contexts'. Studies in Second Language Acquisition 26/2: 173-99.

Serrano, R., À. Llanes, and E. Tragant. 2011. 'Analyzing the effect of context of second language learning: domestic intensive and semi-intensive courses vs. study abroad in Europe'. System 39/2: 133-43.

Tragant, E. 2012. 'Change or stability in learners' perceptions as a result of study abroad' in C. Muñoz (ed.). Intensive Exposure Experiences in Second Language Learning. Clevedon: Multilingual Matters.

Viladoms, J. 2009. Pesquis i Baliga. Barcelona: Cavall Fort.

\section{The authors}

Raquel Serrano is Lecturer in the Department of English Studies at the University of Barcelona (Spain), where she teaches undergraduate and postgraduate courses in Applied Linguistics and Bilingualism. Her current research explores the effect of learning context and time distribution on the acquisition of English as a foreign language, focusing on language development in different programme types.

\section{Email: raquelserrano@ub.edu}

Elsa Tragant is an Associate Professor of Applied Linguistics at the University of Barcelona, where she teachers research methods and ESL methods courses. Her recent publications have focused on the role of context in foreign language learning, L2 motivation, language learning strategies, and classroom research.

\section{Email: tragant@ub.edu}

Àngels Llanes received her $\mathrm{PhD}$ on Applied Linguistics at the University of Barcelona (Spain). She is currently a lecturer in the Department of English and Linguistics at the University of Lleida (Spain), where she teaches undergraduate and postgraduate courses. Her research mostly focuses on the role of age and learning context on L2 development.

\section{Email: allanes@dal.udl.cat}


Table 1. Language tasks measures

\begin{tabular}{|l|l|}
\hline DIMENSION & MEASURE \\
\hline Fluency & Total number of words \\
\hline Lexical Complexity & $\begin{array}{l}\text { Guiraud's Index } \\
\text { computed by dividing the types of words a learner } \\
\text { wrote by the square root of the different instances } \\
\text { (tokens) }\end{array}$ \\
\hline Accuracy & $\begin{array}{l}\text { Bubbles: Ratio of errors with respect to the total } \\
\text { number of words } \\
\text { Narrative: Ratio of lexically correct verbs out of the } \\
\text { total number of verbs }\end{array}$ \\
\hline
\end{tabular}


Table 2. Descriptive statistics pre- and post-test all participants (bubbles)

\begin{tabular}{lcccc}
\hline & \multicolumn{2}{c}{$\begin{array}{c}\text { SA } \\
(\mathrm{N}=54)\end{array}$} & \multicolumn{2}{c}{$\begin{array}{c}\text { Intensive AH } \\
(\mathrm{N}=58)\end{array}$} \\
\hline & \multicolumn{5}{c}{ Pre-test } \\
\cline { 2 - 5 } & Mean & SD & Mean & SD \\
Fluency (Words) & 67.13 & 20.17 & 51.48 & 14.80 \\
Lexical Complexity (Guiraud's Index) & 5.53 & 0.7 & 5.11 & 0.67 \\
Accuracy (Ratio errors) & 6.07 & 6.90 & 7.54 & 5.03 \\
\hline & \multicolumn{5}{c}{ Post-test } \\
& 75.37 & 22.22 & 64.51 & 20.91 \\
Fluency (Words) & 5.71 & 0.69 & 5.39 & 0.71 \\
Lexical Complexity (Guiraud's Index) & 5.77 & 5.65 & 7.17 & 4.22 \\
Accuracy (Ratio errors) & \multicolumn{5}{c}{. }
\end{tabular}


Table 3. Descriptive statistics pre- and post-test all participants (narrative)

\begin{tabular}{lcccc}
\hline & \multicolumn{2}{c}{$\begin{array}{c}\text { SA } \\
(\mathrm{N}=54)\end{array}$} & $\begin{array}{c}\text { Intensive AH } \\
(\mathrm{N}=58)\end{array}$ \\
\hline & \multicolumn{4}{c}{ Pre-test } \\
\cline { 2 - 5 } & Mean & SD & Mean & SD \\
& & & & \\
& 91.65 & 25.99 & 81.88 & 21.39 \\
Fluency (Words) & 5.74 & 0.75 & 5.49 & 0.80 \\
Lexical Complexity (Guiraud's Index) & 74.46 & 21.75 & 67.20 & 20.94 \\
Accuracy (Ratio correct verbs) & \multicolumn{5}{c}{ Post-test } \\
& 104.61 & 30.82 & 91.05 & 24.82 \\
& 6.09 & 0.82 & 5.66 & 0.64 \\
Fluency (Words) & 79.46 & 19.71 & 69.11 & 19.04 \\
Lexical Complexity (Guiraud's Index) & \multicolumn{5}{c}{ Accuracy (Ratio correct verbs) } &
\end{tabular}


Table 4. Results learners' characteristics and experience

\begin{tabular}{|c|c|c|}
\hline FACTOR & OPERATIONALIZATION & RESULTS \\
\hline \multirow{5}{*}{ Initial predisposition } & \multirow[t]{2}{*}{$\begin{array}{l}\text { Motivation to enrol in the } \\
\text { programme (Q1) }\end{array}$} & $\begin{array}{l}\text { SA: } 43 \% \text { parents' idea; } 43 \% \text { students' } \\
\text { idea }\end{array}$ \\
\hline & & AH: 79\% parents’ idea \\
\hline & \multirow[t]{2}{*}{ Motivation to learn English (Q2) } & $\begin{array}{l}\text { SA: } 28 \% \text { quite motivated; } 47 \% \text { very } \\
\text { motivated } \\
\text { (variety of intrinsic and extrinsic } \\
\text { motivation) }\end{array}$ \\
\hline & & $\begin{array}{l}\text { AH: } 53 \% \text { quite motivated; } 16 \% \text { very } \\
\text { motivated } \\
\text { (mostly extrinsic motivation) }\end{array}$ \\
\hline & Easiness to learn English (Q3) & $\begin{array}{l}\text { Comparable results SA and AH: } \\
\text { majority (around 90\%) falling } \\
\text { between more or less and quite easy. }\end{array}$ \\
\hline \multirow{3}{*}{$\begin{array}{l}\text { English use during } \\
\text { the programme }\end{array}$} & $\begin{array}{l}\text { Experience in the English class } \\
\text { (Q4, Q5) }\end{array}$ & $\begin{array}{l}\text { Comparable results: most students } \\
\text { (90\%) using English almost always or } \\
\text { always (especially with teachers) }\end{array}$ \\
\hline & \multirow[t]{2}{*}{$\begin{array}{l}\text { Experience outside of class (Q4, } \\
\text { Q6, Q7) }\end{array}$} & $\begin{array}{l}\text { SA: quite diverse, ranging from } \\
\text { almost never to sometimes in dining } \\
\text { room; sometimes-often in afternoon } \\
\text { activities; sometimes in the residence } \\
\text { hall; few times-sometimes during } \\
\text { weekends }\end{array}$ \\
\hline & & $\begin{array}{l}\text { AH: mostly for homework and mostly } \\
\text { grammar and vocabulary }\end{array}$ \\
\hline \multirow{8}{*}{$\begin{array}{l}\text { Students’ } \\
\text { perceptions }\end{array}$} & \multirow[b]{2}{*}{$\begin{array}{l}\text { Favourite aspect of programme } \\
\text { (Q8) }\end{array}$} & SA: $59 \%$ meeting people: $23 \%$ trips \\
\hline & & $\begin{array}{l}\text { AH: diverse answers, mostly focusing } \\
\text { on the type of activities (audio-visual, } \\
\text { games, computer, etc.) }\end{array}$ \\
\hline & \multirow[b]{2}{*}{$\begin{array}{l}\text { Most helpful aspect to learn } \\
\text { (Q9) }\end{array}$} & $\begin{array}{l}\text { SA: } 60 \% \text { meeting new people; } 25 \% \text { : } \\
\text { contact with natives }\end{array}$ \\
\hline & & $\begin{array}{l}\text { AH: diverse answers, including the } \\
\text { teacher, activities, intensive schedule, } \\
\text { etc. }\end{array}$ \\
\hline & \multirow{2}{*}{$\begin{array}{l}\text { Willingness to enrol in same } \\
\text { programme next year (Q10) }\end{array}$} & SA: $68 \%$ surely; $26 \%$ probably \\
\hline & & AH: 45\% probably; 26\% maybe \\
\hline & \multirow{2}{*}{$\begin{array}{l}\text { Perception of English learning } \\
\text { (Q11) }\end{array}$} & $\begin{array}{l}\text { SA: } 48 \% \text { some learning; } 35 \% \text { little } \\
\text { learning }\end{array}$ \\
\hline & & AH: $50 \%$ some learning; $32 \%$ a lot \\
\hline
\end{tabular}


Appendix A

\section{Tony and Tina}

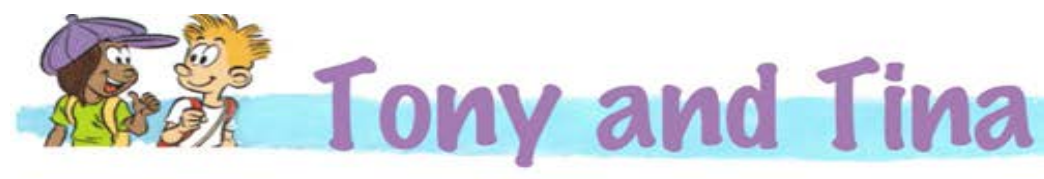

bY VILADOMS
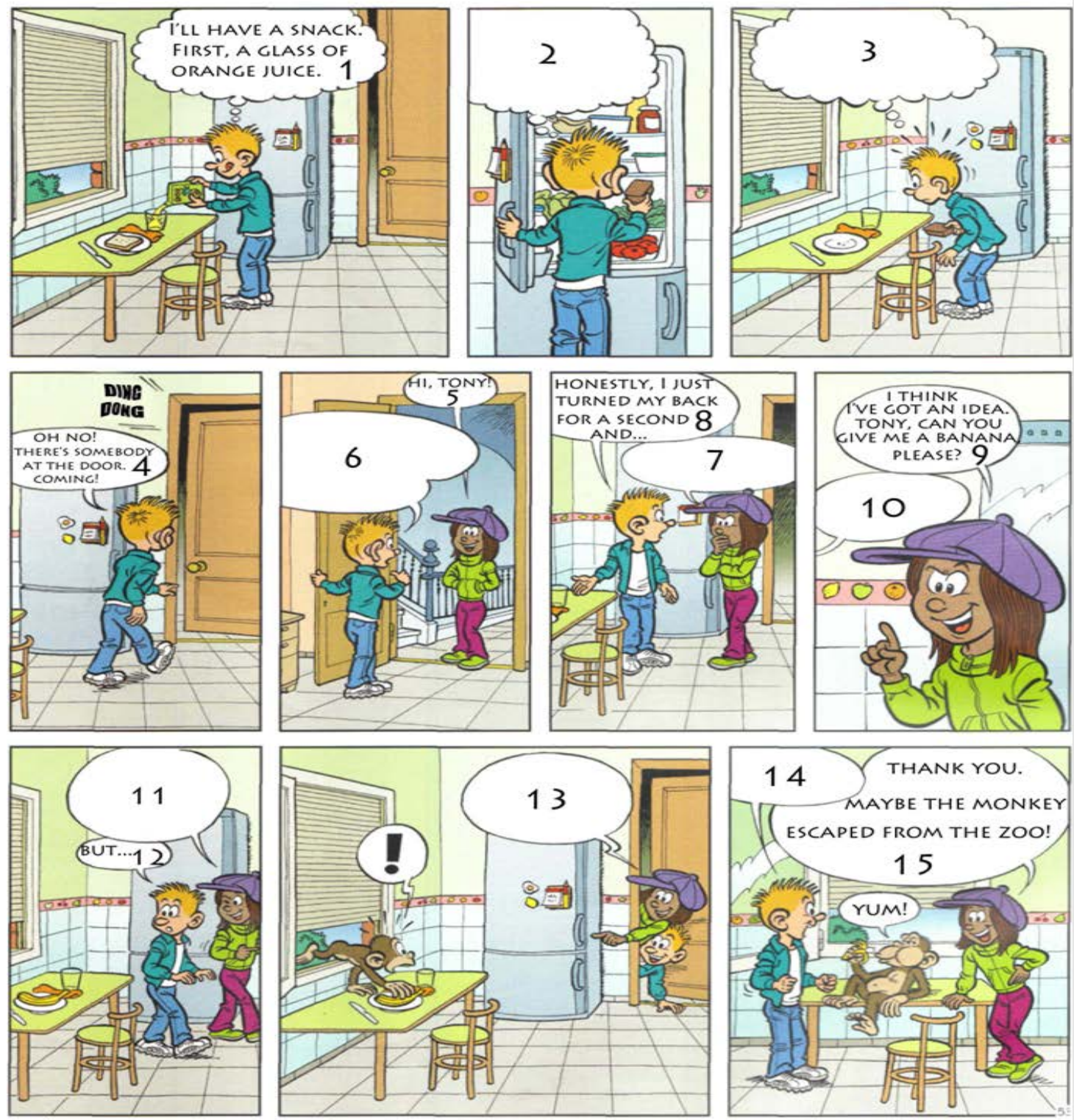

Pesquis i Baliga-CF1119@Cavall Fort 2009, by Viladoms. All rights reserved. 


\section{Appendix B}

Results RM ANOVA time and context

\begin{tabular}{|c|c|c|c|}
\hline & Time & Context & Time*Context \\
\hline $\begin{array}{l}\text { Bubbles fluency } \\
\text { (Words) }\end{array}$ & $\begin{array}{l}F(1,110)=39.40 \\
p<.001 \\
\text { partial } \eta^{2}=.266\end{array}$ & $\begin{array}{l}F(1,110)=15.89 \\
p<.001 \\
\text { partial } \eta^{2}=.126\end{array}$ & $\begin{array}{l}F(1,110)=2.03 \\
p=.157 \\
\text { partial } \eta^{2}=.018\end{array}$ \\
\hline $\begin{array}{l}\text { Bubbles lexical complexity } \\
\text { (Guiraud's index) }\end{array}$ & $\begin{array}{l}F(1,110)=15.54 \\
p<.001 \\
\text { partial } \eta^{2}=.124\end{array}$ & $\begin{array}{l}F(1,110)=9.19 \\
p=.003 \\
\text { partial } \eta^{2}=.077\end{array}$ & $\begin{array}{l}F(1,110)=.710 \\
p=.401 \\
\text { partial } \eta^{2}=.006\end{array}$ \\
\hline $\begin{array}{l}\text { Bubbles accuracy } \\
\text { (Ratio errors) }\end{array}$ & $\begin{array}{l}F(1,110)=.499 \\
p=.481 \\
\text { partial } \eta^{2}=.005\end{array}$ & $\begin{array}{l}F(1,110)=2.39 \\
p=.125 \\
\text { partial } \eta^{2}=.021\end{array}$ & $\begin{array}{l}F(1,110)=.005 \\
p=.942 \\
\text { partial } \eta^{2}=.000\end{array}$ \\
\hline $\begin{array}{l}\text { Narrative fluency } \\
\text { (Words) }\end{array}$ & $\begin{array}{l}F(1,110)=25.71 \\
p<.001 \\
\text { partial } \eta^{2}=.191\end{array}$ & $\begin{array}{l}F(1,110)=7.00 \\
p=.009 \\
\text { partial } \eta^{2}=.060\end{array}$ & $\begin{array}{l}F(1,110)=.753 \\
p=.388 \\
\text { partial } \eta^{2}=.007\end{array}$ \\
\hline $\begin{array}{l}\text { Narrative lexical complexity } \\
\text { (Guiraud's index) }\end{array}$ & $\begin{array}{l}F(1,110)=25.59 \\
p<.001 \\
\text { partial } \eta^{2}=.190\end{array}$ & $\begin{array}{l}F(1,110)=6.33 \\
p=.013 \\
\text { partial } \eta^{2}=.055\end{array}$ & $\begin{array}{l}F(1,110)=2.90 \\
p=.093 \\
\text { partial } \eta^{2}=.026\end{array}$ \\
\hline $\begin{array}{l}\text { Narrative accuracy } \\
\text { (Ratio correct verbs) }\end{array}$ & $\begin{array}{l}F(1,110)=5.87 \\
p=.017 \\
\text { partial } \eta^{2}=.051\end{array}$ & $\begin{array}{l}F(1,110)=5.99 \\
p=.016 \\
\text { partial } \eta^{2}=.052\end{array}$ & $\begin{array}{l}F(1,110)=1.18 \\
p=.281 \\
\text { partial } \eta^{2}=.011\end{array}$ \\
\hline
\end{tabular}




\section{Appendix C}

\section{Extract from the questionnaire}

Relevant questions from the questionnaires (the original questions form part of a longer questionnaire which was administered in the students’ L1).

1 Whose idea was it for you to enrol in this programme?
Parents
$\square$ Yours
Someone else:

2 Do you like learning English?

$\square$ Very little $\quad \square$ A little $\quad \square$ Quite $\quad \square$ A lot $\square$ Really a lot Why?

3 Do you think English is easy for you?
$\square$ No
Not much
$\square$ More or less
$\square$ Yes, quite
$\square$ Yes, very

4 How often did you use English in the following contexts? (For SA students only)

\begin{tabular}{|l|l|l|l|l|l|}
\hline & Almost & $\begin{array}{l}\text { A few } \\
\text { times }\end{array}$ & Sometimes & Often & $\begin{array}{l}\text { Almost } \\
\text { always }\end{array}$ \\
\hline English class & & & & & \\
\hline Dining room & & & & & \\
\hline $\begin{array}{l}\text { Programmed } \\
\text { afternoon } \\
\text { activities }\end{array}$ & & & & & \\
\hline Residence hall & & & & & \\
\hline
\end{tabular}




\begin{tabular}{|l|l|l|l|l|l|}
\hline $\begin{array}{l}\text { Free time and } \\
\text { weekends }\end{array}$ & & & & & \\
\hline
\end{tabular}

5 In general, how often have you used English with the following people? (For AH students only)

\begin{tabular}{|l|l|l|l|l|l|}
\hline & $\begin{array}{l}\text { Hardly } \\
\text { ever }\end{array}$ & Sometimes & Often & $\begin{array}{l}\text { Almost } \\
\text { always }\end{array}$ & Always \\
\hline Classmates (in class) & & & & & \\
\hline Classmates (breaks) & & & & & \\
\hline Teachers (in class) & & & & & \\
\hline Teachers (breaks) & & & & & \\
\hline
\end{tabular}

6 During this month, how much English have you used AT HOME/DURING YOUR FREE TIME (for homework or activities you did)? Please mark everything that applies. (For AH students only)

\begin{tabular}{|l|l|l|l|l|l|}
\hline & $\begin{array}{l}\text { Very } \\
\text { little }\end{array}$ & A little & Quite & A lot & $\begin{array}{l}\text { Really a } \\
\text { lot }\end{array}$ \\
\hline Speaking & & & & & \\
\hline $\begin{array}{l}\text { Listening (TV, films, songs, } \\
\text { etc.) }\end{array}$ & & & & & \\
\hline Reading & & & & & \\
\hline Writing & & & & & \\
\hline
\end{tabular}




\begin{tabular}{|l|l|l|l|l|l|}
\hline Grammar & & & & & \\
\hline Vocabulary & & & & & \\
\hline
\end{tabular}

7 Most of the times you practised your English OUTSIDE THE CLASS was because of ...? (For AH students only)
$\square$ Homework
Other reasons:

8 What was your favourite aspect of the programme?

9 What was it that has helped you learn English the most during this course?

10 Would you like to enrol in this programme again next year?
$\square$ No
$\square$ I don’t think so
Maybe
$\square$ Probably
For sure

11 In general, how much English have you learnt in this summer course?
$\square$ Very little
$\square$ A little
$\square$ Quite
$\square$ A lot
$\square$ Really a lot 